\title{
PENENTUAN PENERIMA BERAS RASKIN DI KELURAHAN OESAPA BARAT MENGGUNAKAN METODE K-NEAREST NEIGHBOR (KNN)
}

\author{
Yampi R Kaesmetan ${ }^{1}$ \\ ${ }^{1}$ Stikom Uyelindo Kupang, Jl. Perintis Kemerdekaan 1 Kayu Putih, Kupang - NTT \\ Email: kaesmetanyampi@.com \\ Marmi Yusri Taek ${ }^{2}$ \\ Stikom Uyelindo Kupang, Jl. Perintis Kemerdekaan I, Kayu Putih, Kupang, NTT \\ Email: taek_marmi@yahoo.com
}

\begin{abstract}
Rapid technological developments are currently very influential in all areas of work especially in the field of mapping the location on maps online. Village of West Oesapa, District Kelapa Lima, Kupang is one of the villages that aspires for the welfare of the community by way of distribution of poor rice aid to the poor in the economic field. Raskin rice distribution should be shared equitably and meets the criteria as a poor rice recipient in the Village of West Oesapa. With KNN method (K-Nearest Neighbor) will count how many people in each neighborhood would receive help poor rice in accordance with existing criteria, and to determine the percentage can be seen in the form of a map.
\end{abstract}

\section{PENDAHULUAN}

Perkembangan zaman yang semakin hari semakin pesat, kebutuhan akan pangan dan papan yang juga semakin tinggi khususnya kebutuhan pangan membuat masyarakat miskin yang penghasilannya dibawah rata-rata sangat sulit mendapatkan pangan. Oleh karena itu pemerintah memberikan bantuan berupa beras miskin (Raskin) kepada masyarakat untuk membantu memenuhi kecukupan pangan. Sasaran utama pemberian beras miskin dikhususkan hanya untuk masyarakat yang berpenghasilan dibawah rata-rata.

Kelurahan Oesapa Barat, Kecamatan Kelapa Lima, Kota Kupang merupakan salah satu kelurahan yang memiliki peranan penting untuk mensejahterakan masyarakat dengan bantuan pembagian beras raskin kepada masyarakat yang kurang mampu yang ada di kelurahan Oesapa Barat. Di kelurahan Oesapa Barat proses pemberian beras raskin belum dilaksanakan sepenuhnya karena jumlah masyarakat miskin di setiap RT jumlahnya tidak selalu sama setiap tahun melainkan jumlahnya berbeda, ada yang meningkat dan ada juga yang menurun. Proses perhitungan data penduduk miskin di kelurahan yang dilakukan setiap tahun dalam penentuan penerima beras untuk keluarga miskin (Raskin) masih menggunakan cara manual dan database yang digunakan masih dalam bentuk kertas, sehingga membutuhkan waktu yang lama untuk pengolahan dan kendala terbesar adalah kesulitan dalam penyimpanan atau pencarian arsip yang telah tersimpan jika akan dicocokkan dengan informasi atau pedoman yang baru diperoleh, serta tak lupa masalah pembuatan laporan yang terlambat terkadang juga menghambat penyampaian informasi.

Penyaluran beras (Raskin) lewat tiap-tiap RT, ketua RT yang mensurvey untuk pengisian kriteria setiap keluarga. Pihak kelurahan yang menentukan layak atau tidaknya keluarga tersebut menerima Raskin. Pengambilan keputusan untuk menentukan kriteria penerima beras yang sudah terjadi biasanya tidak mengacu pada kriteria-kriteria keluarga miskin. Kriteria yang digunakan untuk penentuan penerimaan beras raskin adalah pekerjaan, dan penghasilan yang didapat.

Metode yang digunakan dalam penentuan penerima beras raskin adalah metode $\mathrm{KNN}(K$ Nearest Neighbor). Data mining adalah suatu istilah yang digunakan untuk menguraikan penemuan pengetahuan di dalam database. Data mining adalah proses yang menggunakan teknik statistik, matematika, kecerdasan buatan, dan machine learning untuk mengekstraksi dan mengidentifikasi informasi yang bermanfaat dan pengetahuan yang terkait dari berbagai database besar (Turban,dkk. 2005). Alasan dipilihnya 
metode $\mathrm{KNN}(K$-Nearest Neighbor $)$ karena metode ini dapat memenuhi variabel-variabel yang lain dalam penentuan penerima beras raskin dan juga metode ini merupakan metode yang digunakan dalam pengklasifikasian untuk mencari jarak terdekat antara data yang akan dievaluasi dengan tetangga terdekatnya dalam data pelatihan. Penghitungan jarak menggunakan rumus Euclidean Distance.

\section{METODE PENELITIAN}

Metodologi adalah suatu cara kerja yang digunakan untuk membangun suatu sistem yang baru. Metodologi penelitian yang akan digunakan dalam penelitian ini terdiri dari langkah-langkah berikut:

Dalam melakukan penelitian ini penulis menggunakan atau melakukan beberapa tahapan yang dilakukan untuk mendapatkan informasi dari penelitian yang dilakukan oleh penulis yaitu mempelajari referensi-referensi yang terkait dalam penelitian ini.

a. Observasi

Digunakan untuk mencari dan mengumpulkan data tersebut dengan meneliti dokumen-dokumen yang berhubungan dengan sistem yang ada pada perpustakaan untuk mengetahui sistem yang lama. Observasi dilaksanakan di Kantor Lurah Oesapa Barat

b. Wawancara

Mengumpulkan data dengan wawancara dengan menanyakan secara langsung petugas perpustakaan. Dan menanyakan semua permasalahan permasalahan yang terjadi didalam kelurahan Oesapa Barat untuk memperoleh permasalahan yang dapat dipecah dan di temukan jalan keluar dari masalah yang didapatkan melalui wawancara.

\section{c. Studi Perpustakaan}

Dilakukan dengan cara membaca dan mempelajari literatur, buku-buku, skripsi-skripsi, serta artikel-artikel yang mendukung dengan topik yang akan dibahas dalam penyusunan skripsi ini. Selain itu juga penulis mengumpulkan data dari situs-situs internet yang berhubungan dengan penelitian penulis.
Vol. 2, No. 2, Desember, 2016

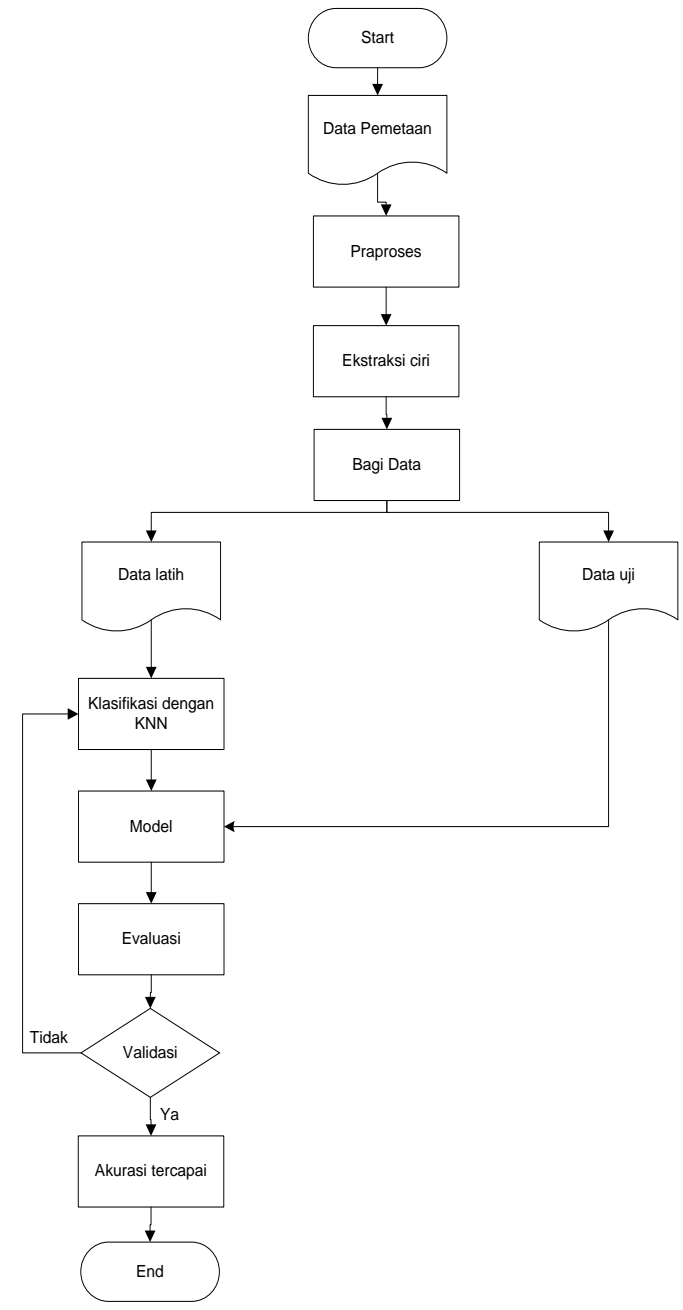

\section{HASIL DAN PEMBAHASAN}

Pada bagian ini akan dijelaskan tentang hasil dan pembahasan untuk penentuan penerima beras raskin di keluruhan Oesapa Barat setiap RT.

\section{a. Beras Miskin (Raskin)}

Dalam kamus besar bahasa Indonesia (KBBI,1990) beras mempunyai dua arti antara lain padi yang telah terkupas kulitnya (yang menjadi nasi setelah dimasak) dan biji-bijian atau butirbutiran seperti jagung atau kopi, sedangkan miskin artinya tidak berharta benda, serba kekurangan (berpenghasilan sangat rendah).

Dalam pedoman umum raskin menjelaskan bahwa pemerintah Indonesia memberikan prioritas yang besar terhadap kebijakan ketahanan pangan nasional. Indonesia turut menandatangani kesepakatan internasional terkait dengan pangan yaitu Universal Declaration of Human Right (1948). Tingkat komsumsi beras masyarakat Indonesia jauh diatas rata-rata dunia dimana negara lain mengkomsumsi beras hanya sebatas 600 $\mathrm{Kg} / \mathrm{kapita} / \mathrm{tahun}$. Dengan demikian Indonesia menjadi Negara konsumen beras terbesar di dunia. 
Beras menjadi komoditas nasional yang sangat strategis. Instabilitas perberasan nasional dapat mengakibatkan gejolak dalam berbagai aspek kehidupan baik sosial, politik, maupun ekonomi.

Peranan komoditi makanan terhadap garis kemiskinan jauh lebih besar dibandingkan dengan komoditi bukan makanan seperti perumahan, sandang, pendidikan dan kesehatan. Sumbangan makanan terhadap garis kemiskinan pada bulan Maret 2014 tercatat sebesar 73,52\%, kondisi ini tidak jauh berbeda dengan kondisi sebelumnya di tahun 2013 yaitu 73,50\%. Komoditi makanan berpengaruh besar terhadap nilai garis kemiskinan antara lain beras, rokok, telur, ayam, mie instan, gula pasir, tempe dan bawang merah.

Program raskin merupakan implementasi dari instruksi presiden tentang kebijakan perberasan nasional. Presiden menginstruksikan kepada para mentri dan kepala lembaga pemrintah non kementrian tertentu, serta gubernur dan bupati/walikota di seluruh Indonesia untuk melakukan upaya peningkatan pendapatan petani, ketahanan pangan, pengembangan ekonomi pedesaan dan stabilitas ekonomi nasional. Secara khusus kepada Perum BULOG diinstruksikan untuk menyediakan dan menyalurkan beras bersubsidi bagi kelompok masyarakat berpendapatan gabah atau beras dari petani dalam negeri.

Penyaluran beras bersubsidi bagi kelompok masyarakat berpendapatan rendah bertujuan untuk mengurangi beban pengeluaran para RTS-PM dalam memenuhi kebutuhan pangan. Selain itu juga untuk meningkatkan akses masyarakat berpendapatan rendah dalam pemenuhan kebutuhan pangan pokok, sebagai salah satu hak dasarnya. Sasaran program raskin tahun 2015 adalah berkurangnya beban pengeluaran dana anggaran nasional dalam mencukupi kebutuhan pangan beras melalui penyaluran beras raskin di seluruh Indonesia.

\section{b. Algoritma K Nearest Neighbor}

Metode K-Nearest Neighbor merupakan salah satu metode yang digunakan dalam pengklasifikasian data. Prinsip kerja $K$-Nearest Neighbor (KNN) adalah mencari jarak terdekat antara data yang akan di evaluasi dengan $\mathrm{K}$ tetangga (neighbor) terdekatnya dalam data pelatihan (Rismawan, dkk. 2008).

Berikut rumus pencarian jarak menggunakan rumus Euclidean (Sutanto,2009).

$$
d_{i j}=\sqrt{\sum_{i=1}^{p}\left(x_{i k}-x_{j k}\right)^{2} \ldots \ldots(1)}
$$

Keterangan:

$$
\begin{aligned}
& \mathrm{X}_{\mathrm{jk}}=\text { Sample Data } / \text { Data Training } \\
& \mathrm{X}_{\mathrm{ik}}=\text { Data Uji / Testing } \\
& \mathrm{ij}=\text { Variabel Data } \\
& \mathrm{d} \quad=\text { Jarak } \\
& \mathrm{p} \quad=\text { Dimensi Data }
\end{aligned}
$$

KNN (K-Nearest Neighbor) merupakan salah satu metode yang digunakan dalam menyelesaikan masalah pengklasifikasian. KNN (K-Nearest Neighbor) yaitu mengelompokkan atau mengklasifikasikan suatu data baru yang belum diketahui kelasnya berdasarkan jarak data baru itu ke beberapa tetangga (neighbor) terdekat. Tetangga terdekat adalah objek latih yang memiliki nilai kemiripan terbesar atau ketidakmiripan terkecil dari data lama. Jumlah tetangga terdekat dinyatakan dengan $k$. Nilai $k$ yang terbaik tergantung pada data. Secara umum nilai $k$ yang tinggi akan mengurangi efek noise pada klasifikasi, tetapi membuat batasan antara setiap klasifikasi menjadi semakin kabur. Pada kasus khusus dimana klasifikasi diprediksikan berdasarkan data sampel yang paling dekat yaitu $k=1$ yang disebut dengan Nearest Neighbor.

Nilai $k$ umumnya ditentukan dalam jumlah ganjil $(3,5,7)$ untuk menghindari munculnya jumlah jarak yang sama dalam proses pengklasifikasian. Apabila terjadi dua atau lebih jumlah kelas yang muncul sama maka nilai $k$ menjadi $k-1$ (satu tetangga kurang), jika masih ada yang sama lagi maka nilai $k$ menjadi $k-2$, begitu seterusnya sampai tidak ditemukan lagi kelas yang sama banyak.

Prinsip kerja KNN (K-Nearest Neighbor) adalah mencari jarak terdekat antara data yang akan dievaluasi dengan tetangga (neighbor) terdekatnya dalam data pelatihan. Pada KNN ( $K$ Nearest Neighbor) tidak hanya menghasilkan satu jarak terpendek saja, tetapi akan menghasilkan sebanyak $k$ jarak terpendek (Kusumadewi, 2009). Banyaknya kelas yang paling banyak dengan jarak terdekat akan menjadi kelas dimana data yang dievaluasi berada. Dekat atau jauhnya tetangga (neighbor) biasanya dihitung berdasarkan jarak Euclidean (Euclidean Distance).

Input:

$\mathrm{k}$, the number of nearest neighbors;

$\mathrm{D}$, the set of test sample;

$\mathrm{T}$, the set of training sample.

Output: 
L, the label set of test sample.

1: readDataFile(TrainingData)

2: readDataFile(TestingData)

3: $\mathrm{L}=\{\}$

4: for each $\mathrm{d}$ in $\mathrm{D}$ and each $\mathrm{t}$ in $\mathrm{T}$ do

5: $\operatorname{Neighbors}(\mathrm{d})=\{\}$

6: if $|\operatorname{Neighbors}(\mathrm{d})|<\mathrm{k}$ then

7: $\quad \operatorname{Neighbors}(d)=\operatorname{Closest}(d, t) \cup \operatorname{Neighbors}(d)$

8: endif

9: if $|\operatorname{Neighbors}(d)| \geq k$ then

10: break

11: L =testClass(Neighbors(d)) U L

12: endfor

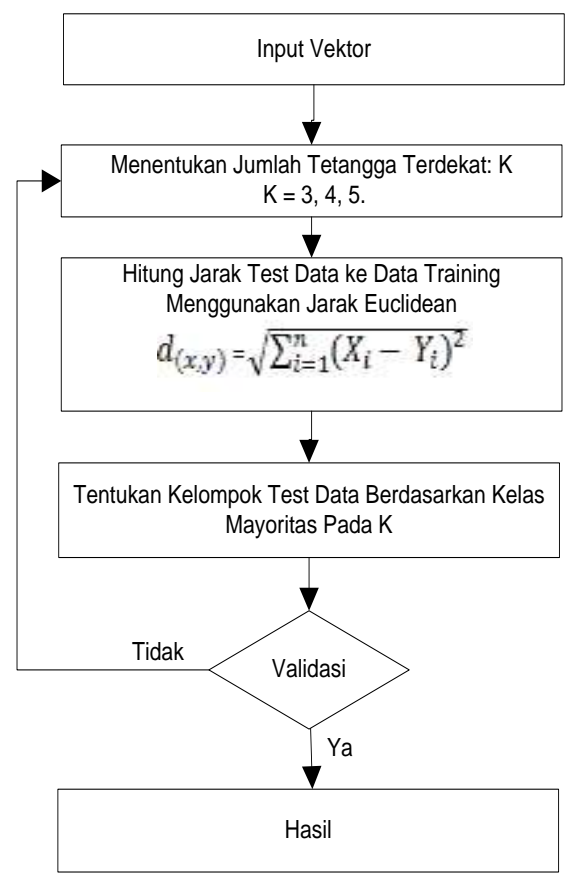

\section{Bagi Data}

Data pemetaan yang telah melalui tahap praposes kemudian dibagi dengan $k$-fold. Metode $\mathrm{k}$-fold cross validation merupakan skenario dimana membagi sama rata dari seluruh data yang ada untuk dijadikan sebagai data testing pada setiap foldnya. yaitu 100 data. Jika $\mathrm{k}$ yang digunakan adalah 4-fold, maka metode yang digunakan adalah 4-fold cross validation. Dataset dibagi menjadi data training dan data testing, sebesar $75 \%$ untuk data training dan $25 \%$ untuk data testing [7].

Tabel 1. 4-fold cross validation

\begin{tabular}{ccccc}
\hline & \multicolumn{3}{c}{ Data Latih } & Data Uji \\
\hline Skenario 1 & F2 & F3 & F4 & F1 \\
& \multicolumn{5}{c}{$75 \%$} & & $25 \%$ \\
Skenario 2 & F1 & F3 & F4 & F2 \\
& \multicolumn{5}{c}{$75 \%$} & & $25 \%$ \\
Skenario 3 & F1 & F2 & F4 & F3 \\
Skenario 4 & F1 & $75 \%$ & & $25 \%$ \\
& & $75 \%$ & F3 & F4 \\
\hline
\end{tabular}

\section{Evaluasi}

Evaluasi penentuan kualitas benih jagung berdasarkan tingkat kecerahan warna, dilakukan untuk memprediksi seberapa baik classifier memprediksi label kelas tupel. Sensitivitas dan spesifitas dapat digunakan untuk penentuan label tupel, sensitivitas disebut juga sebagai tupel positif yang bernilai benar, sedangkan spesifisitas adalah tupel negatif yang bernilai benar. Cara mencari nilai sensitivitas dan spesifitas dapat dirumuskan dengan

[6].

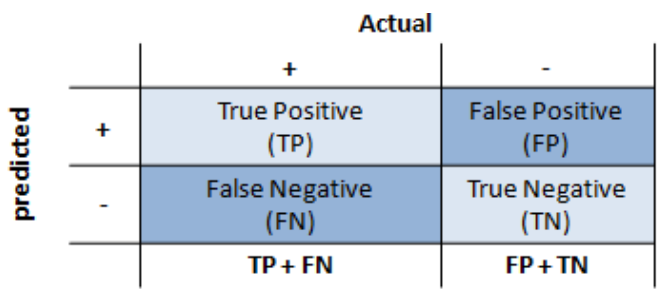

Gambar 8. Confusion Matrix

Sensitivitas $=\frac{T P}{T P+F N}$

Spesifisitas $=\frac{T N}{T N+F P}$.

Sedangkan akurasi keseluruhan dihitung dengan:

Akurasi $=\frac{\mathrm{TP}+\mathrm{TN}}{\mathrm{TP}+\mathrm{TN}+\mathrm{FN}+\mathrm{FP}} \times 100 \%$

\section{c. Perhitungan Manual}

Pada tahap ini akan dilakukan analisis permasalahan, analisis kebutuhan sistem, dan analisis pemecahan masalah dengan menggunakan metode K-Nearest Neighbor dengan menghitung jarak euclidean untuk mencari tahu penerima beras raskin di kelurahan Oesapa Barat untuk semua RT. Sebelum perhitungan lanjut menggunakan metode algoritma KNN data sampel yang akan dipakai yaitu data tentang pekerjaan dan data jumlah penghasilan. Untuk data pekerjaan dan data jumlah penghasilan di dapatkan dari pakar dalam mengisi nilai untuk kedua data variabel tersebut. Untuk memperoleh status penerima beras raskin data pekerjaan dan jumlah penghasilan yang diberikan oleh pakar akan dijadikan sebagai data training. 
Berikut adalah data hasil pekerjaan dan jumlah penghasilan yang diberikan oleh pakar.

Tabel 1. Data training untuk status penerima raskin

\begin{tabular}{|c|c|c|}
\hline Pekerjaan & $\begin{array}{r}\text { Jumlah } \\
\text { penghasilan }\end{array}$ & Status \\
\hline 100 & 50 & Tidak \\
\hline 125 & 34 & Tidak \\
\hline 110 & 43 & Tidak \\
\hline 135 & 40 & Tidak \\
\hline 145 & 30 & Ya \\
\hline 167 & 47 & Tidak \\
\hline 170 & 48 & Tidak \\
\hline 163 & 38 & Ya \\
\hline 189 & 25 & Ya \\
\hline 152 & 50 & Tidak \\
\hline
\end{tabular}

Pada tabel diatas nilai pekerjaan meliputi pekerjaan petani, wiraswasta, pedagang, tukang dan lain-lain yang bukan pegawai. Nilai pekerjaan dan jumlah penghasilan merupakan nilai bobot yang diberikan oleh pakar penerima raskin.

Pada perhitungan manual ini diambil 10 data KK yang dianggap layak untuk menerima bantuan raskin dalam setiap RT. Data sampel yang akan dipakai untuk menghitung jarak euclidean dengan metode KNN ditentukan sendiri oleh user, data sampelnya yaitu 3 dan 2 sedangkan parameter $\mathrm{K}$ nilainya 3. Perhitungan dengan menggunakan metode KNN adalah sebagai berikut:

1) Menghitung jarak euclidean

$$
\begin{aligned}
\text { Data } 1 & =\sqrt{(100-3)^{2}+(50-2)^{2}}=108,2 \\
\text { Data } 2 & =\sqrt{(125-3)^{2}+(34-2)^{2}}=126,1 \\
\text { Data } 3 & =\sqrt{(110-3)^{2}+(43-2)^{2}}=114,5 \\
\text { Data } 4 & =\sqrt{(135-3)^{2}+(40-2)^{2}}=137,3 \\
\text { Data5 } 5 & =\sqrt{(145-3)^{2}+(30-2)^{2}}=144,7 \\
\text { Data6 } 6 & =\sqrt{(167-3)^{2}+(47-2)^{2}}=170,1 \\
\text { Data7 } & =\sqrt{(170-3)^{2}+(48-2)^{2}}=173,2 \\
\text { Data } 8 & =\sqrt{(163-3)^{2}+(38-2)^{2}}=164 \\
\text { Data } 9 & =\sqrt{(189-3)^{2}+(25-2)^{2}}=187,4 \\
\text { Data10 } & =\sqrt{(152-3)^{2}+(50-2)^{2}}=156,5
\end{aligned}
$$

Dari satu yang sudah dilakukan perhitungan diatas maka selanjutnya kita melakukan perangkingan terhadap ke-10 buah data yang sudah dilakukan perhitungan jarak euclidean.

2) Melakukan perangkingan data

Pada tabel ini kita melakukan perangkingan dari hasil perhitungan manual menghitung jarak dengan rumus euclidean. Setelah itu urutkan data berdasarkan jarak terkecil sampai besar (urut naik) dan tentukan jarak terdekat sampai urutan nilai $k=$ 3 , maka diambil 3 jarak terkecil sehingga di dapat tabel seperti di bawah ini:

Tabel 2. Perangkingan data jarak euclidean

\begin{tabular}{c|c|c}
\hline Rank & Euclidean & Status \\
\hline 1 & 108.2 & Tidak \\
\hline 3 & 126.1 & Tidak \\
\hline 2 & 114.5 & Tidak \\
\hline 4 & 137.3 & Tidak \\
\hline 5 & 144.7 & Ya \\
\hline 8 & 170.1 & Tidak \\
\hline 9 & 173.2 & Tidak \\
\hline 7 & 164 & Ya \\
\hline 10 & 187.4 & Ya \\
\hline 6 & 156.5 & Tidak \\
\hline
\end{tabular}

Setelah menentukan 3 buah data perangkingan yang terkecil maka didapat hasil tabel $\mathrm{K}$ seperti dibawah ini:

Dari data tabel diatas bisa diketahui bahwa dari 3 tetangga terdekat menunjukkan terdapat 3 status penerima beras raskin tidak mendapatkan, maka hasil akhirnya di RT 01 kelurahan Oesapa Barat dari 10 data $\mathrm{KK}$ yang diambil tidak ada yang mendapatkan bantuan beras raskin dengan status perhitungannya "Tidak".

\section{d. Implemntasi Program}

Pada tahap implementasi dalam program ini menggunakan matlab dimana matlab yang digunakan dalam bentuk GUI dan membuka file untuk melakukan perhitungan sistem dengan file berformat .xlsx atau excel.

1) Tampilan awal antarmuka

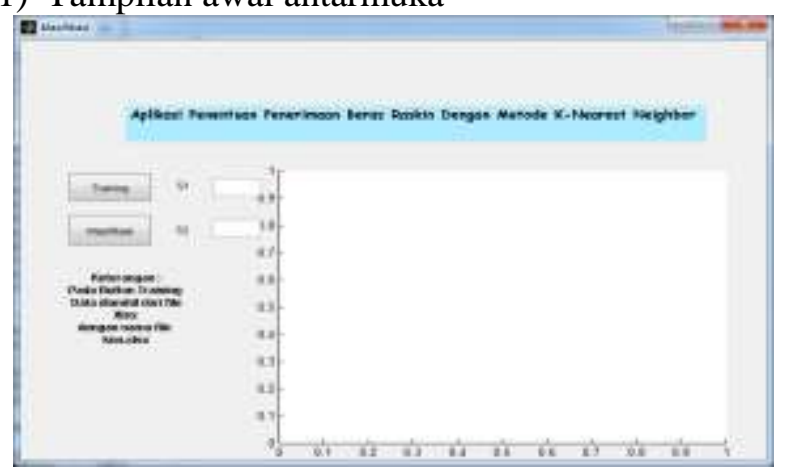

Gambar 1. Tampilan awal antarmuka sistem

2) Tampilan proses inputan 


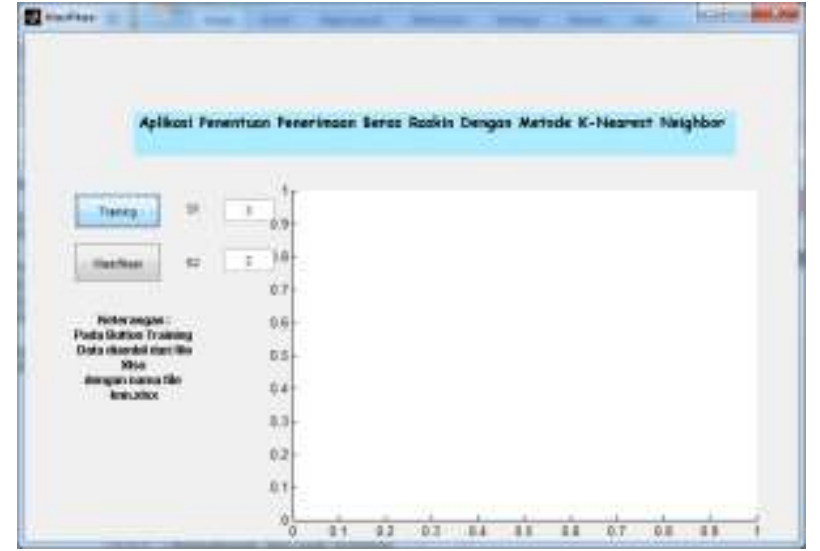

Gambar 2. Tampilan proses inputan

3) Tampilan proses perhitungan

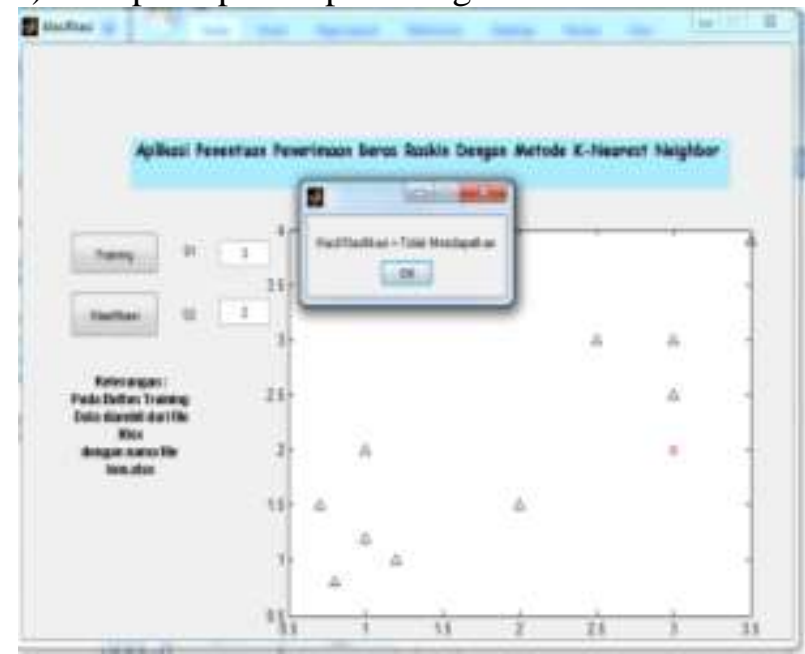

Gambar 3. Tampilan proses perhitungan

Dari hasil perhitungan diatas pada sistem yang dibuat hasilnya sama dengan perhitungan manual tidak ada yang mendapatkan bantuan beras raskin.

\section{e. Pemetaan pada peta}

Pada tahap ini akan dibuat pemetaan penerima beras raskin di kelurahan Oesapa Barat yang dipetakan di dalam peta.

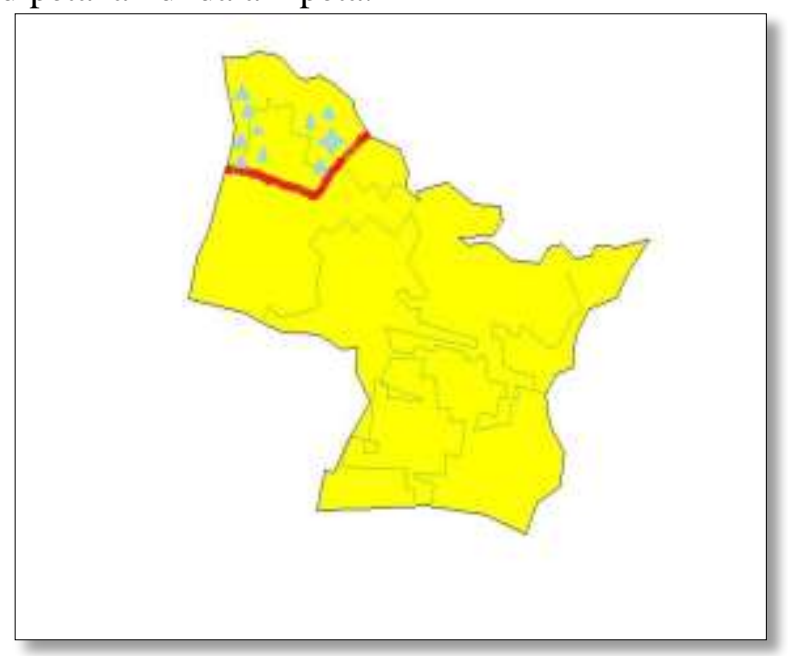

Gambar 4. Peta pemetaan penerima beras raskin
Pada peta diatas dicari berapa banyak masyarakat di RT 01 kelurahan Oesapa Barat yang berhak menerima bantuan beras raskin yang sudah menjadi program desa dari pemerintahan di Kota Kupang. Dari peta yang dilihat diatas bahwa dalam RT 01 tidak ada yang mendapatkan bantuan beras raskin karena dilihat dari segi ekonomi semua KK yang berada dalam lingkungan RT 01 semuanya mempunyai pekerjaan dan jumlah penghasilan yang cukup untuk memenuhi kebutuhan pangan dalam keluarga.

\section{f. Evaluasi}

Dilihat dari nilai $k$, maka $k=3$ menghasilkan nilai yang paling besar pada sensitivitas, spesifisitas, dan akurasi. Hal ini menunjukkan bahwa semakin kecil nilai $k$ yang digunakan maka error rate yang dihasilkan semakin kecil. Hasil perhitungan sensitivitas dapat dilihat pada gambar 5, dan gambar 6 untuk perhitungan spesifisitas. Untuk akurasi ditunjukkan pada gambar 7.

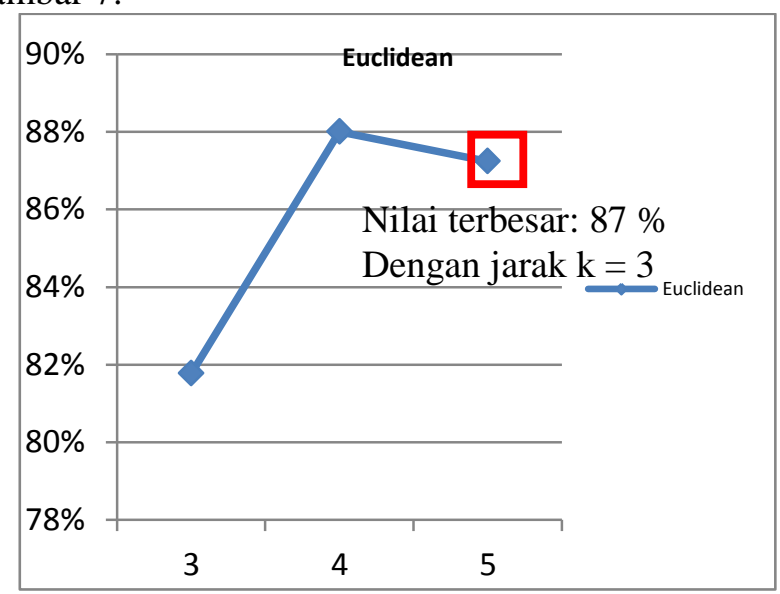

Gambar 5. Perhitungan sensitivitas

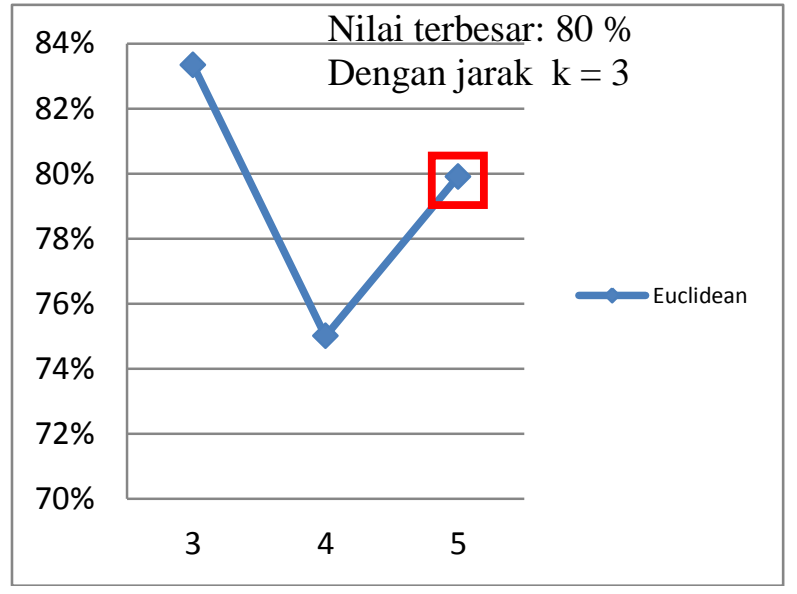

Gambar 6. Perhitungan spesifisitas 


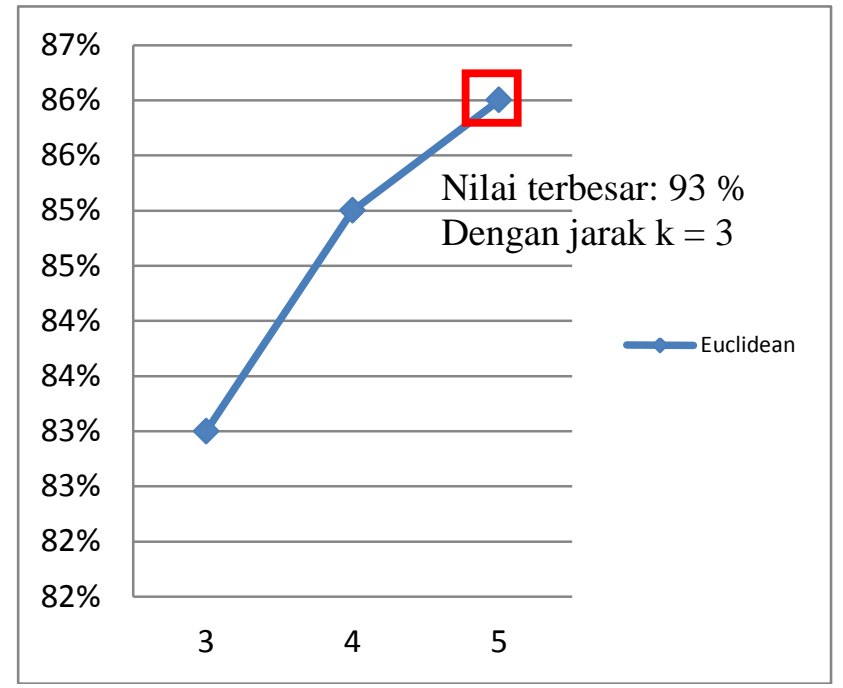

Gambar 7. Perhitungan akurasi
Meningkatkan Ketahanan Pangan. Fakultas Ekonomi. Universitas Sultan Agung Triyatsa. Vol 14

\section{PENUTUP}

\section{Kesimpulan}

Berdasarkan hasil dan pembahasan yang peneliti lakukan mengenai klasifikasi status penerimaan bantuan beras miskin menggunakan metode K-Nearest Neighbor dengan melibatkan variabel pekerjaan dan jumlah penghasilan $\mathrm{KK}$, dapat disimpulkan bahwa penerapan metode KNearest Neighbor dalam pengklasifikasian status gizi dengan menggunakan formulasi perhitungan jarak eucledian memiliki kinerja yang baik. Dengan metode KNN peneliti dapat menemukan berapa banyak $\mathrm{KK}$ yang dapat bantuan raskin sesuai prosedur dan kriteria yang sudah dikeluarkan oleh pemerintah Kota Kupang.

\section{DAFTAR PUSTAKA}

Kusrini dan Luthfi, M. 2009. Algoritma Data Mining. Yogyakarta : Penerbit Andi Offset.

Kusumadewi, S.2009. Klasifikasi Status Gizi Menggunakan Nä̈ve Bayesian Classification. Yogyakarta. Universitas Islam Indonesia.

Sutabri, T. 2004. Analisa Sistem Informasi Yogyakarta : Penerbit Andi.

Hasan, I. 2012. Penerapa Algoritma K-Nearest Neighbor Untuk Prediksi Potensi Calon Kreditur Di XYZ Finance. Universitas Negeri Gorontalo.

Darliani R. N. Kebijakan Program Perindustrian Beras Miskin Dalam Upaya Menanggulangi Kemiskinan Dan 